\title{
Optical, thermal, strength properties and SHG efficiency of KDP single crystals doped with $\mathbf{N}, \mathbf{N}^{\prime}$-dimethyl urea
}

\author{
E.I.Kostenyukova ${ }^{1}$, O.N.Bezkrovnaya ${ }^{1}$, E.F.Dolzhenkova ${ }^{1}$, I.M.Pritula $^{1}$, \\ A.G.Doroshenko ${ }^{1}$, M.A.Chaika ${ }^{1}$, A.G.Fedorov ${ }^{2}$, S.V.Khimchenko ${ }^{2}$ \\ ${ }^{1}$ Institute for Single Crystals, STC "Institute for Single Crystals", \\ National Academy of Sciences of Ukraine, \\ 60 Nauky Ave., 61001 Kharkiv, Ukraine \\ ${ }^{2}$ Division of Functional Materials Chemistry, SSI "Institute for Single \\ Crystals", National Academy of Sciences of Ukraine, \\ 60 Nauky Ave., 61001 Kharkiv, Ukraine
}

Received November 27, 2017

Pure single crystals of potassium dihydrophosphate (KDP) and the ones doped with N,N'-dimethylurea (NN'DU) were grown by the temperature reduction method onto a point seed. The dopant concentration in the mother liquor was 0.15 and $0.45 \mathrm{wt}$. \%. The study of the transmission spectra of KDP:NN'DU crystals, as well as the change in their strength properties (mechanical and laser strength) and thermal properties (differential thermal and thermogravimetric analyses) in the growth sectors $\{101\}$ and $\{100\}$ confirms the occurrence of NN'DU molecules in both growth sector. It was shown that doping of the crystals with NN'DU molecules led to an increase in the efficiency of second harmonic generation by two times in the sector $\{100\}$ of KDP:NN'DU crystals as compared with pure KDP.

Keywords: KDP crystals, N,N'-dimethylurea, laser damage threshold, microhardness, nonlinear optic materials.

Чистые и допированные N,N'-диметилмочевиной (NN'DU) монокристаллы дигидрофосфата калия (KDP) выращены методом снижения температуры на точечной затравке. Концентрация допанта в маточном растворе составляла 0,15 и 0,45 масс.\%. Исследованы спектры пропускания кристаллов KDP:NN'DU, а также изменение их прочностных (механическая и лазерная прочности) и термических (дифференциально-термический и термогравиметрический анализы) свойств в секторах роста $\{101\}$ и $\{100\}$, что подтверждает наличие молекул NN'DU в обоих секторах роста. Показано, что допирование кристаллов KDP молекулами NN'DU привело к увеличению әффективности генерации второй гармоники в два раза в секторе $\{100\}$ по сравнению с чистым KDP.

Оптичні, термальні, міцнісні властивості та ефективність ГдГ монокристалів KDP, допованих $\mathbf{N}, \mathbf{N}$ '-диметилмочевиною. О.І.Костенюкова, О.М.Безкровна, О.Ф.Долженкова, І.М.Притула, А.Г.Дорошенко, М.А.Чайка, О.Г.Федоров, С.В.Хилченко.

Чисті та доповані N,N'-диметилмочевиною (NN'DU) монокристали дигідрофосфату калію (KDP) вирощено методом зниження температури на точковій затравці. Концентрація допанту у маточному розчині склала 0,15 та 0,45 мас. \%. Дослідження спектрів пропускання кристалів KDP:NN'DU, а також змінення їх міцнісних (механічна та лазерна міцності) та термічних (диференціально-термічний та термогравіметричний аналізи) властивостей у секторах росту $\{101\}$ та $\{100\}$ підтверджує присутність молекул NN'DU в обох секторах росту. Показано, що допування кристалів KDP молекулами NN'DU призвело до збільшення ефективності генерації другої гармоніки у два рази у секторі $\{100\}$ у порівнянні з чистим KDP. 


\section{Introduction}

Well-known inorganic matrices, such as KDP $\left(\mathrm{KH}_{2} \mathrm{PO}_{4}\right)$ group crystals with nonlinear optical (NLO) properties, are often used to create new NLO materials by doping them with various organic and inorganic additives [1-4]. They continue to be popular as electro-optical materials (including those meant for production of optical elements) due to a relatively simple growth of crystals of required dimensions with good optical homogeneity. The use of KDP crystals in nonlinear optics is due to their high structural perfection, transparency in the UV region of the spectrum, and a relatively high threshold of laser destruction.

However, one of the main functional limitations of the use of KDP crystals in NLO applications is a relatively low value of the quadratic susceptibility $\left(d_{36(\mathrm{KDP})}=\right.$ $0.38 \mathrm{pm} / \mathrm{V}$ [5]). There were introduced various additives the crystals in order to raise quadratic susceptibility of KDP, including molecules of organic compounds (Xylenol orange dye [1], amino acids [2-4, 6, 7]) and metal oxide nanoparticles [8,9]. The introduction of amino acids into the crystal matrix led to an increase in the efficiency of second harmonic generation (SHG) by 1.75 times for KDP containing L-alanine [10], and by 1.14 times for KDP containing L-valine and L-threonine [3, 4], in comparison with that for the pure crystal. The doping of KDP with L-arginine amino acid led to the rise of NLO coefficients in comparison with that for the pure crystal by $1.33-$ 1.74 times [2] and by $\sim 2.5$ times in the case of KDP:L-arginine crystals [6,7]. The additives are found to influence the growth of the doped crystals and their physicochemical characteristics.

The authors of [10] assumed that molecules of an organic additive could slightly distort KDP crystal lattice, thereby causing local deformations and polarization. Xue [11] shows the dominant contribution of $\mathrm{PO}_{4}$ groups to the overall nonlinearity of $\mathrm{KH}_{2} \mathrm{PO}_{4}$ crystal. In addition, the increase in the SHG efficiency of doped KDP crystals may also be affected by the rise in the number of hydrogen bonds formed when some organic molecules are introduced into the crystal structure $[12,13]$. It is known that hydrogen bond in some NLO inorganic crystals, such as $\mathrm{HIO}_{3}, \mathrm{NH}_{4} \mathrm{H}_{2} \mathrm{PO}_{4}, \mathrm{KH}_{2} \mathrm{PO}_{4}$, plays a very important role in the overall nonlinearity of the crystals. However, KDP crystals have only $\mathrm{O}-\mathrm{H} \cdots \mathrm{O}$ type hydrogen bonds, while the crystals of $\mathrm{NH}_{4} \mathrm{H}_{2} \mathrm{PO}_{4}$ group have two types of hydrogen bonds: $\mathrm{O}-\mathrm{H} \cdots \mathrm{O}$ and $\mathrm{N}-\mathrm{H} \cdots \mathrm{O}$ [13]. Both KDP and $\mathrm{NH}_{4} \mathrm{H}_{2} \mathrm{PO}_{4}$ crystals have similar anionic structural units of $\mathrm{H}_{2} \mathrm{PO}_{4}^{-}$, but different cationic units $\left(\mathrm{K}^{+}\right.$and $\left.\mathrm{NH}_{4}^{+}\right)$. As reported in [13], in $\mathrm{NH}_{4} \mathrm{H}_{2} \mathrm{PO}_{4}$ crystals the hydrogen bonds $\mathrm{N}-\mathrm{H} \ldots \mathrm{O}$ make significant NLO contribution to the overall nonlinearity of the crystal (the coefficient $d_{36}$ ). In KDP-type crystals, despite the fact that the hydrogen bonds are disordered and centrosymmetric, they may contribute to the NLO properties such as quadratic electrooptical effect, nonlinear refractive index or harmonic generation [14].

In $[15,16]$ urea molecules were introduced into KDP crystals to increase the NLO properties. In this case, the amino groups present in urea structure replaced the potassium ions of KDP crystal matrix, which facilitated the entry of urea molecules into the crystal. In addition, urea molecules formed hydrogen bonds with the growing crystal faces. The introduction of additives into KDP crystals affects on the strength and other properties of the crystal matrix. As shown in [15], KDP:Urea crystals have higher mechanical properties than the pure crystals $(\sim 10 \%$ at loads of $15-100 \mathrm{~g}$ in the sector $\{100\})$. The laser strength of KDP:Urea single crystals is increased by 20-25\% (when using YAG: $\mathrm{Nd}^{3+}$ laser at $1.064 \mu \mathrm{m})$ compared to the one of the pure crystals [16]. The SHG efficiency of KDP:Urea single crystals increased approximately by 1.2 times as compared to that of pure KDP (for the crystals grown from the solutions containing $0.2-2 \mathrm{M}$ Urea) [16].

It is known that 1,3-dimethyl urea (or $\mathrm{N}, \mathrm{N}$ '-dimethylurea, NN'DU) urea derivative, has high NLO properties [17]. Moreover, NN'DU molecules contribute to the increase in the NLO properties of L-arginine phosphate monohydrate [17] and KDP crystals [18]. The structure of NN'DU molecules contains $\mathrm{C}=\mathrm{O}$ group, which has acceptor properties and two $\mathrm{N}\left(\mathrm{CH}_{3}\right) \mathrm{H}$ groups, which have donor properties. The presence of $\mathrm{H}, \mathrm{O}$, and $\mathrm{N}$ atoms in the structure of NN'DU may influence the formation of multiple hydrogen bonds between molecules and $\mathrm{H}_{2} \mathrm{PO}_{4}$ groups of KDP crystal, which leads to a modification of the properties of the crystal matrix [17]. Thus, it was of interest to grow a bulk KDP single crystal doped with NN'DU molecules and investigate the effect of the 

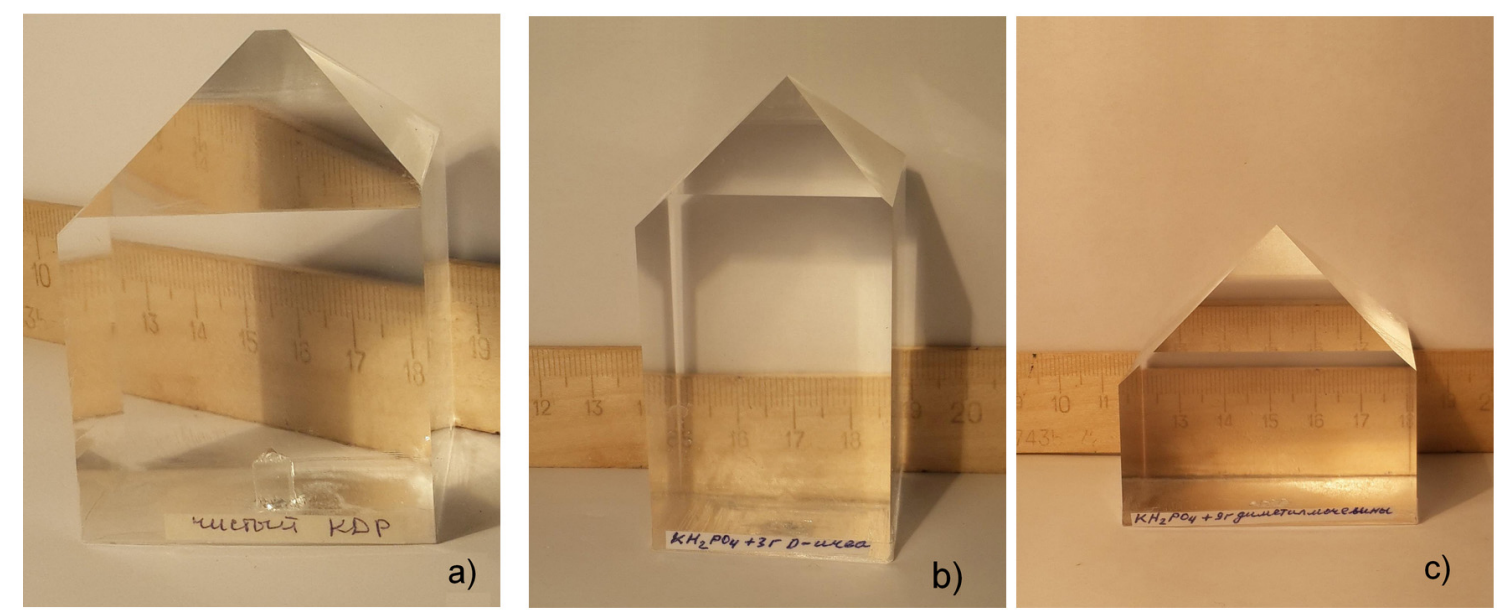

Fig. 1. Photo of pure KDP (a) and KDP:NN'DU crystals with NN'DU of different concentration in the mother liquid: 0.15 wt. $\%$ (b) and 0.45 wt. \% (c).

dopant on the change in the properties of KDP crystal.

In the present work we studied the influence of NN'DU molecules on the optical (linear and nonlinear) properties of KDP crystals grown from the solutions by the temperature lowering method. The influence of NN'DU molecules on the structural, strength (laser-induced damage threshold and microhardness) and thermal characteristics of doped KDP crystals was investigated.

\section{Experimental}

Pure and doped KDP single crystals were grown from aqueous solutions $(\mathrm{pH} 4.0 \pm 0.1)$ onto a point seed measuring $5 \times 5 \times 10 \mathrm{~mm}^{3}$ by the temperature lowering method in a $6.0 \mathrm{~L}$ crystallizer at a saturation temperature of $50^{\circ} \mathrm{C}$. NN'DU $\left(\mathrm{CH}_{3} \mathrm{HNCONHCH}{ }_{3}\right.$, pure $\geq 99 \%$, Aldrich) was used for doping KDP crystals at concentrations of 0.15 and 0.45 wt. $\%$ in the mother liquor (on the weight of $\mathrm{KH}_{2} \mathrm{PO}_{4}$ salt). The content of microimpurities ( $\mathrm{Fe}, \mathrm{Al}, \mathrm{Cr}, \mathrm{Mg}, \mathrm{Mn}$, etc.) in $\mathrm{KH}_{2} \mathrm{PO}_{4}$ salt was not higher than $10^{-5}$ wt. \%. The temperature was lowered at a rate of $0.3^{\circ} \mathrm{C} /$ day and $0.4^{\circ} \mathrm{C} /$ day for $\mathrm{KDP}$ and KDP:NN'DU crystals, respectively. The solution in the crystallizer was stirred at a speed of $70 \mathrm{rpm}$ to provide dynamic growth conditions for the crystals. The crystals were grown dyring 1.5-2 months and had well-developed growth sectors $\{100\}$ and \{101\} (Fig. 1). The average crystal growth rate was 1.4 and $1.0 \mathrm{~mm}$ /day for pure KDP, 1.3 and $0.6 \mathrm{~mm} /$ day for KDP:0.15 NN'DU and 1.3 and $1.2 \mathrm{~mm} /$ day KDP:0.45 NN'DU crystals. The samples measuring $10 \times 10 \times 10 \mathrm{~mm}^{3}$ with the sides parallel to the planes (100) and (001) were cut out from the crystal growth sectors $\{100\}$ and $\{101\}$ of the grown crystals for studies of their optical transmission, laser and mechanical strength. Then the samples were ground and polished.

The optical transmission of the crystals was studied in the spectral range of 200$1100 \mathrm{~nm}$ wavelengths using a Lambda 35 PerkinElmer spectrophotometer. The laserinduced damage threshold (LIDT) of the samples of KDP and KDP:NN'DU crystals was studied at the fundamental wavelength of YAG: $\mathrm{Nd}^{3+}$ laser operating at $\lambda=1.06 \mu \mathrm{m}$. During the measurements the energy of single-mode laser radiation pulse was $2.75 \mathrm{~mJ}$, with $1 \mathrm{~Hz}$ the frequency of pulse repetition, the pulse duration $\tau=10 \mathrm{~ns}, 1 / e$-radius of the focused spot being $45 \mu \mathrm{m}$. The focus of the optical system was located in the crystal bulk. The samples were irradiated by laser pulses at each point according to the scheme $n-1-n$ (90 positions were irradiated at the same energy with the light propagating in the Z-direction, the samples were moved in the plane perpendicular to the laser beam). The laser damage criterion was a spark of high-temperature glow visually observed at the crystal breakdown.

The Vicker's microhardness $\left(H_{V}\right)$ was investigated using a PMT-3 instrument in the load range of $10-200 \mathrm{~g}$, as described in [6, 7]. The typical indenter descent rate was $1 \mathrm{~mm} / \mathrm{min}$, each load being applied during $10 \mathrm{~s} . H_{V}$ was calculated for each sample from the average of the results of 20 measurements on the planes (100) and (001) in the sectors $\{101\}$ and $\{100\}$; the standard deviation did not exceed $2 \%$. The diagonal 

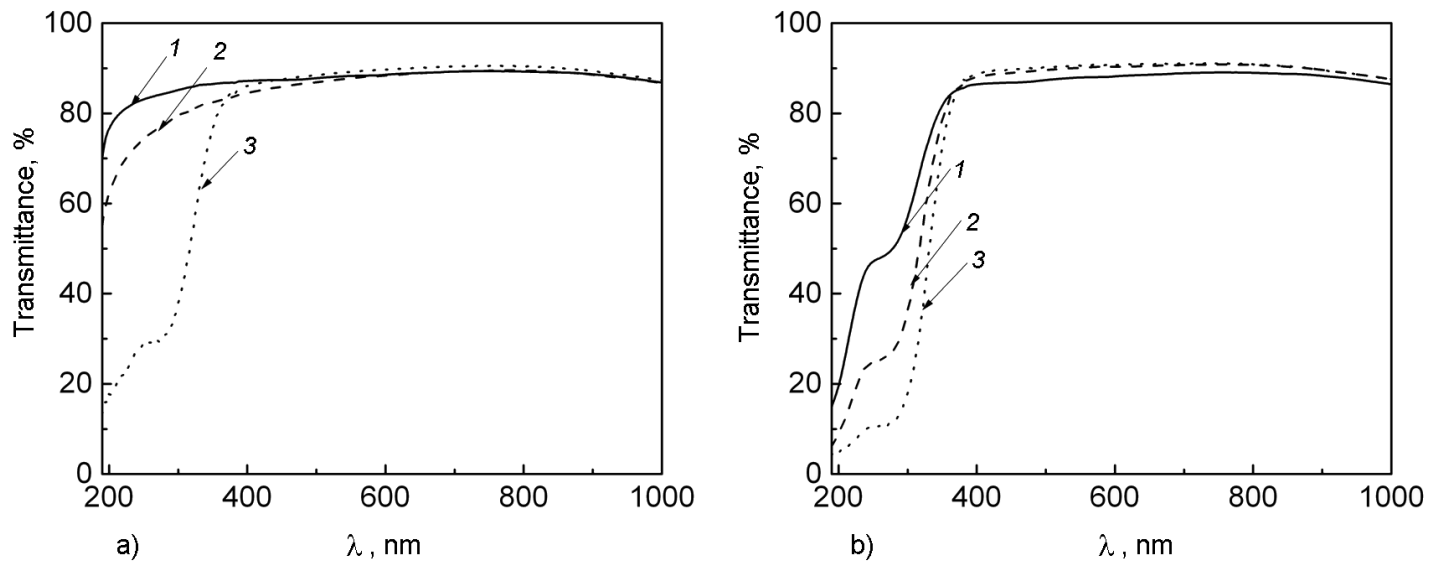

Fig. 2. UV-vis-NIR absorption spectra of KDP:NN'DU crystals for the sectors $\{101\}$ (a) and $\{100\}$ (b) with NN'DU concentrations: 0 wt. $\%$ (1), 0.15 wt. $\%$ (2) and 0.45 wt. $\%$ (3).

prints were measured with an optical microscope ZEISS Axioskop 40. The microhardness value was calculated from the formula:

$$
H_{V}=1.854 P / d^{2}(G P a),
$$

where $H_{V}$ is the microhardness according to Vickers; $P$, the applied load $(N)$; $d$, the average value of the measured lengths the diagonals $(m)$.

Differential thermal (DTA) and thermogravimetric (TG) analyses of the crystals were realized on a MOM Q-1500D derivatograph (Hungary) in $20-550^{\circ} \mathrm{C}$ temperature range. The rate of heating was $2.5 \mathrm{deg} / \mathrm{min}$; as a standard, there was used aluminum alphaoxide. The samples of KDP and KDP:NN'DU crystals $(\sim 1 \mathrm{~g})$ for DTA and TG measurements were crushed in a corundum mortar.

The lattice parameters of KDP samples were measured on a general-purpose X-ray diffractometer using $\mathrm{CuK} \alpha_{1}$ radiation and graphite monochromator in a primary beam. Possible adjustment errors were minimized by means of the Bond method [19]. The rocking curves (RC) were obtained with double crystal spectrometer at $\mathrm{CuK} \alpha_{1}$ radiation with silicon monochromator adjusted to the (400) reflection. The used arrangement allows to pick out well-resolved $\mathrm{K} \alpha_{1}$ line of the X-ray spectrum. For the obtaining of RC's in $(n,-m)$ scheme the $(600)$ reflection of KDP samples was chosen, due to its Bragg reflection angle nearest to that of (400) Si. This considerably decreased the rocking curve broadening caused by dispersion. The measured values of Full Width at Half Maximum (FWHM) may be compared with the calculated ones obtained in accord- ance with $[20,21]$. The diffraction line width $\omega$ is given by the Darwin-Prins formula:

$$
\omega=2 r_{e} \frac{\lambda^{2}}{\pi V} \cdot \frac{\left|F_{h k l}\right|}{\sin 2 \theta}
$$

Here, $r_{e}$ is the classical electron radius; $\lambda$, the X-ray wavelength; $V$, the volume of the unit cell; $\theta$, the Bragg diffraction angle; $F_{h k l}$, the structure factor for specified reflection. Then, the angle spread:

$$
\Delta \theta_{\lambda}=\left(\frac{\Delta \lambda}{\lambda}\right)\left(\operatorname{tg} \theta_{M}-\operatorname{tg} \theta_{S}\right) .
$$

Here, $\theta_{M}$ and $\theta_{S}$ are the diffraction angles of the monochromator and the sample, correspondingly. The spectral line width value $\Delta \lambda=0.000462 \AA$ was adopted for CuK $\alpha$ line [22]. Finally, FWHM:

$$
W=\sqrt{\omega_{M}^{2}+\Delta \theta_{\lambda}^{2}+\omega_{S}^{2}} .
$$

Here, $\omega_{M}$ and $\omega_{S}$ are the diffraction line widths for the monochromator and the sample, correspondingly. The obtained value for the used arrangement is 7.2 arc. sec.

The NLO properties of the crystals were studied using $\mathrm{YAG}: \mathrm{Nd}^{+}$laser at $\lambda=$ $1.064 \mu \mathrm{m}$ as described in [7] (with $1 \mathrm{~Hz}$ pulse frequency, $7 \mathrm{~ns}$ pulse duration, $1 \mathrm{~mm}$ laser beam diameter). The samples of pure and doped KDP crystals were cut out at the phase matching angle $\theta=59^{\circ}$ (Type II, oee) from $\{101\}$ and $\{100\}$ growth sectors. The experiment was repeated for different input powers, and the corresponding output power was measured. The values of SHG efficiency were obtained from the ratio of the output to the input power. 

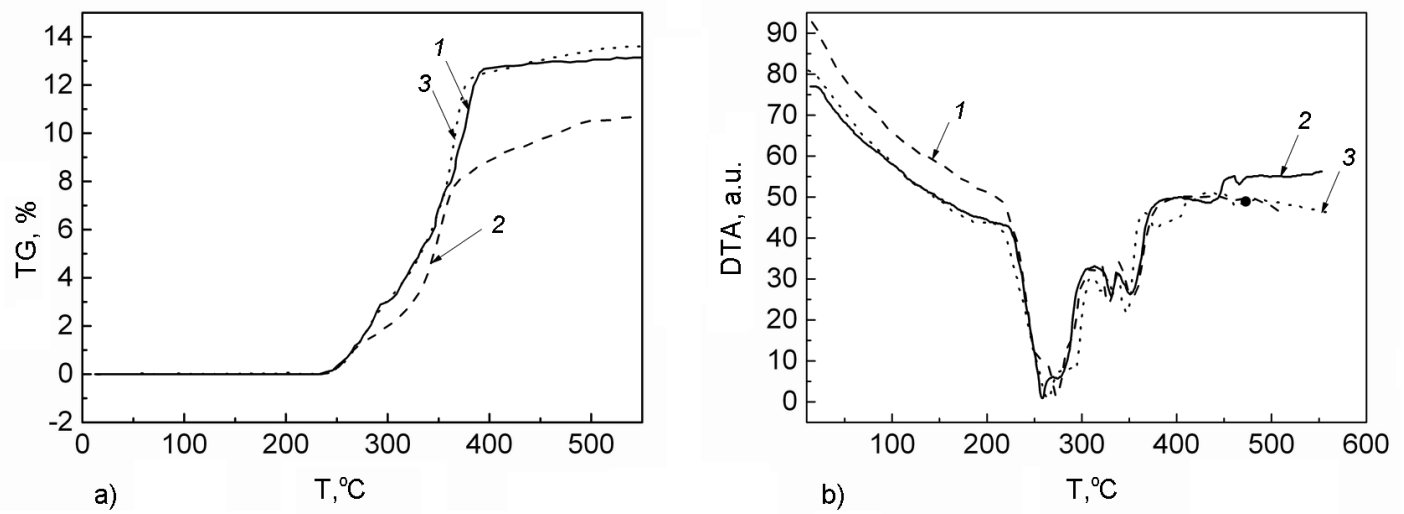

Fig. 3. TGA (a) and DTA (b) spectra of pure KDP crystal (1) and KDP:0.45 wt. \% NN'DU crystal: sector $\{101\}(2)$, sector $\{100\}(3)$.

\section{Results and discussion}

KDP and KDP:NN'DU crystals were transparent and did not contain visible inclusions (Fig. 1). The introduction of NN'DU additives influenced the change of the crystal morphology. A slight blocking of the $\{100\}$ faces of the growing crystal as compared to pure KDP crystal was observed at 0.15 wt. \% NNDU. The increase in the concentration of NN'DU to 0.45 wt. \% also caused blocking of the $\{101\}$ faces.

The transmission of KDP and KDP:NN'DU crystals in the visible region was $\sim 87-$ $90 \%$ (Fig. 2). The decrease in the transmission of pure KDP crystal in 260-280 nm region for the sector $\{100\}$ (curve 1, Fig. 2(a) as compared to that of the sector $\{101\}$ (curve 1, Fig. 2(b) is due to the entry of the metal ions from the starting salt $\mathrm{KH}_{2} \mathrm{PO}_{4}$ into the sector $\{100\}[23,24]$. As seen from Fig. 2, the absorption in the region of $\sim 270 \mathrm{~nm}$ in KDP:NN'DU crystals exceeds the one in the pure KDP for both growth sectors. The increase in the concentration of NN'DU in the mother liquor from 0.15 to 0.45 wt. $\%$ leads to an increase in the absorption (decreasing the transmission) of the crystals in the ultraviolet region of the spectrum. This may be due to entry of NN'DU molecules into both crystal growth sectors. As shown in [16], the occurrence of Urea in KDP crystal increases with the rise of its concentration in the mother liquor.

The presence of the additive in KDP:NN'DU crystal also manifests itself during the measurements of its thermal characteristics. The DTA and TG curves of pure KDP and KDP:NN'DU crystals (the growth sectors $\{101\}$ and $\{100\}$ ) are given in Fig. 3. A continuous 10-13\% loss of the mass of the samples studied is observed at temperatures up to $400^{\circ} \mathrm{C}$. There are distinguished three sections on the TG curve in the temperature ranges of $20-220^{\circ} \mathrm{C}, 220-$ $390^{\circ} \mathrm{C}$ and $390-550^{\circ} \mathrm{C}$. The loss of the mass is insignificant for the first and the third sections due to removal of the adsorbed water (in the first section) and of the residual dehydration products (in the third section). The most intense loss is characteristic of the second section (13\%). Dehydration of KDP crystals is observed in the region of $200-380^{\circ} \mathrm{C}$. On the DTA curve, we observe several exothermic peaks in the $210-380^{\circ} \mathrm{C}$ region, which correspond to dehydration of KDP crystals [25, 26]. The TG curves and peaks on the DTA curve practically coincide for pure KDP and KDP:NN'DU crystals. The decrease in the region of intense mass loss is observed for KDP:NN'DU crystals (intense mass loss ends at $395^{\circ} \mathrm{C}$ for nominally pure $\mathrm{KDP}$, and at $370-380^{\circ} \mathrm{C}$ for the doped crystals). In addition, there is a significant redistribution of the DTA peaks. The redistribution of the intensity of the main DTA peaks at 260 and $275^{\circ} \mathrm{C}$ is due to evaporation of NN'DU (the boiling point of NN'DU is $268-270^{\circ} \mathrm{C}$ ). Therefore, the peak at $260^{\circ} \mathrm{C}$ becomes more intense for the doped crystals. In the high-temperature range (380$550^{\circ} \mathrm{C}$ ), in contrast to nominally pure KDP crystal (for which the mass loss in this region is $0.4 \%)$, the doped crystals show a mass loss of $1.3 \%$ and $2.3 \%$ in the growth sector $\{100\}$ and $\{101\}$, respectively. Obviously, the process of NN'DU evaporation slows down removal of the residual dehydration products of KDP crystals. A more significant distinction for KDP:NN'DU in different growth sectors seems to be due to a greater binding force of NN'DU molecules entering into the sector $\{101\}$, in compari- 
E.I.Kostenyukova et al. / Optical, thermal, strength ...

Table 1. Full Width at Half Maximum (FWHM) values measured in KDP crystals

\begin{tabular}{|c|c|}
\hline Sample & FWHM, arc. sec. \\
\hline Pure KDP, $\{101\}, z$ & 17.0 \\
Pure KDP, $\{100\}, z$ & 18.3 \\
KDP:NN'DU, 0.45 wt. $\%$ NN'DU, $\{101\}, z$ & 14.7 \\
KDP:NN'DU, 0.45 wt. $\%$ NN'DU, $\{100\}, z$ & 15.2 \\
\hline
\end{tabular}

Table 2. Crystal lattice parameters of pure KDP and KDP:NN'DU ( 0.45 wt \% NN'DU) crystals

\begin{tabular}{|c|c|c|c|c||}
\hline Crystals & $c, \AA$ & $a, \AA$ & $\Delta c, \AA$ & $\Delta a, \AA$ \\
\hline Pure KDP, $\{101\}$ & 6.9734 & 7.4528 & - & - \\
Pure KDP, $\{001\}$ & 6.9732 & 7.4526 & - & $-6 \cdot 10^{-4}$ \\
KDP:NN'DU, $\{101\}$ & 6.9729 & 7.4522 & $-5 \cdot 10^{-4}$ & $+1 \cdot 10^{-4}$ \\
KDP:NN'DU, $\{001\}$ & 6.9726 & 7.4527 & $-6 \cdot 10^{-4}$ & + \\
\hline
\end{tabular}

son with the one of the molecules entering into the sector $\{101\}$.

Incorporation of NN'DU molecules into KDP crystal may be due to the formation of hydrogen bonds between the oxygen and nitrogen atoms of NN'DU molecule and $\mathrm{H}_{2} \mathrm{PO}_{4}$ group on the $\{100\}$ face of the growing KDP crystal. Moreover, it may be connected with the interaction between the oxygen atom from the group $\mathrm{C}=\mathrm{O}$ of NN'DU molecules and the face $\{101\}$ of KDP crystal with mainly positive charge [27-29].

To estimate the effect of NN'DU molecules on the structure perfection of the crystals there were measured the rocking curves and the crystal cell parameters $a$ and $c$. The study of the rocking curves showed that the perfection of KDP:NN'DU crystals was extremely good, the crystals had no any internal structural grain boundaries and their perfection corresponded to that of pure KDP crystal (Table 1).

A significant decrease in the lattice parameters as against those of pure KDP ( $\Delta a=$ $-5 \cdot 10^{-4} \AA$ and $\Delta c=-6 \cdot 10^{-4} \AA$ ) was observed for the samples cut out from the growth sectors $\{101\}$ and $\{001\}$ of KDP:NN'DU (0.45 wt. \% NN'DU) (Table 2). It is known that KDP crystal has a tetramolecular unit cell with $a=7.452 \AA$ and $c=6.974 \AA$ [29]. In this case, a significant decrease in the lattice parameter $a$ in the sector $\{101\}(\Delta a=$ $\left.-6 \cdot 10^{-4} \AA\right)$ and its rise in $\{001\}\left(\Delta a=+1 \cdot 10^{-4} \AA\right)$ in comparison with the one of pure KDP is observed for the doped crystal. Thus, KDP:NN'DU (0.45 wt. \% of NN'DU) crystal is characterized by a "contraction" of the unit cell along the directions "c" ([001]) and "a" ([100]) in the sector $\{101\}$, as well as

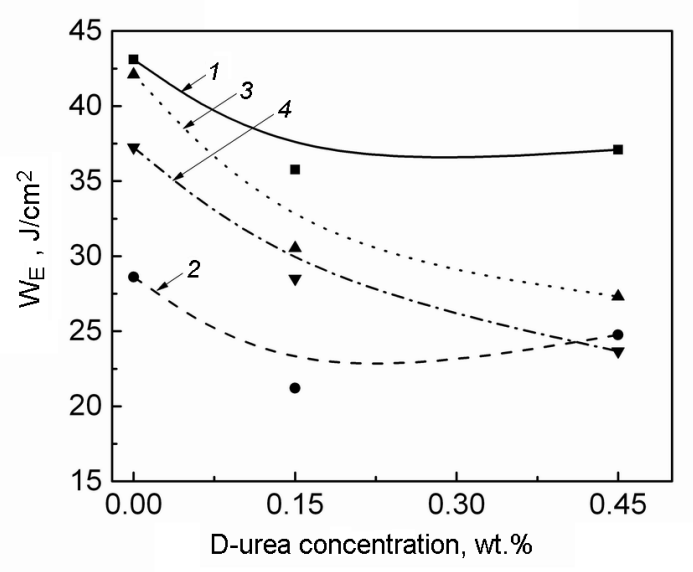

Fig. 4. Dependences of LIDT of KDP:NN'DU crystals on NN'DU concentrations for the samples cut out of the growth sector $\{101\}$ in the directions [001] (1) and of the [100] (2) and sector $\{100\}$ in the directions [001] (3) and [100] (4).

along the direction "c" ([001]) and "stretching" along "a" ([100]) in the sector $\{001\}$ in comparison with pure KDP. This leads to a decrease in the energy of the crystal lattice of KDP matrix due to rearrangements in the hydrogen bond system, and changes in the forces of electrostatic interaction between $\mathrm{K}-\mathrm{O}$ ions.

Resistance to laser radiation is one of the main requirements for the crystals used for converting the frequency of laser radiation. The LIDT of KDP crystals is defined by optical breakdown on absorbing microinhomogeneities, and depends on the presence, nature and distribution of foreign inclusions and growth defects in the crystal.

The performed measurements show that the values of LIDT of both pure and doped 

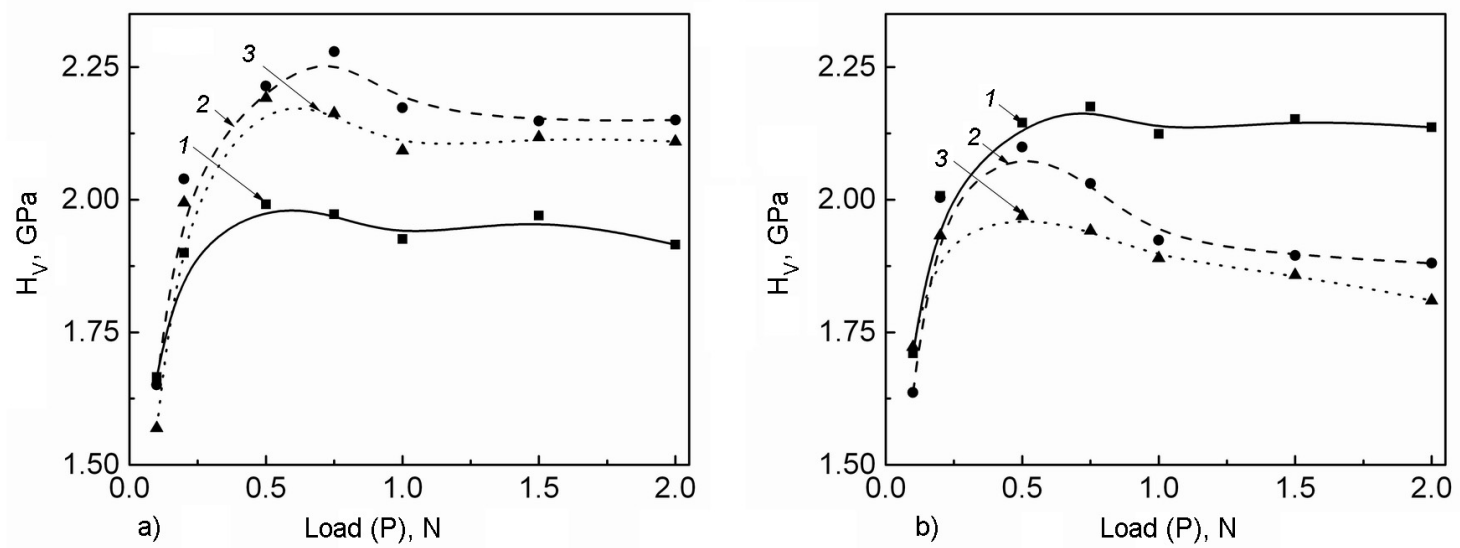

Fig. 5. Microhardness as a function of loadindg for the sectors $\{101\}$ (a) and $\{100\}$ (b) of the plane (001): pure KDP (1), KDP:0.15 wt. \% NN'DU (2), KDP:0.45 wt. \% NN'DU (3).

Table 3. Microhardness of KDP and KDP:NN'DU crystals at indenter load $P=0.75 \mathrm{~N}$

\begin{tabular}{|c|c|c|c|c||}
\hline \multirow{2}{*}{$\begin{array}{c}\text { NN'DU concentra- } \\
\text { tion in the mother } \\
\text { liquor, wt. } \%\end{array}$} & \multicolumn{2}{|c|}{ Sector $\{101\}$} & \multicolumn{2}{c|}{ Sector $\{100\}$} \\
\cline { 2 - 5 } & $(001), \mathrm{GPa}$ & $(001), \mathrm{GPa}$ & $(001), \mathrm{GPa}$ & $(001), \mathrm{GPa}$ \\
0 & 1.973 & 1.935 & 2.176 & 2.066 \\
0.15 & 2.279 & 2.165 & 2.031 & 2.015 \\
0.45 & 2.163 & 1.992 & 1.942 & 1.780 \\
\hline
\end{tabular}

Table 4. SHG efficiency in KDP and KDP:NN'DU crystals at different NN'DU concentrations

\begin{tabular}{|c|c|c||}
\hline $\begin{array}{c}\text { NN'DU concentration in the } \\
\text { mother liquor, wt. \% }\end{array}$ & Sector $\{101\}$ & Sector $\{100\}$ \\
\hline 0 & 1 & 1 \\
0.15 & 0.87 & 1.91 \\
0.45 & 1.03 & 1.94 \\
\hline
\end{tabular}

crystals are higher in [001] direction (compared with those in [100] direction) for the growth sectors $\{100\}$ and $\{101\}$ (Fig. 4). LIDT of KDP:NN'DU crystals decreases with respect to the one for pure KDP by 17$32 \%$ for both growth sectors, the measurement error being $15 \%$ (Fig. 4). However, in [16] it was shown that doping of KDP crystals by urea led to an increase in their LIDT by 20-25\%. The amino groups of urea molecules replace potassium ions in the crystal structure of KDP, causing hardening of the crystal. However, there is no amino group which could replace $\mathrm{K}^{+}$ions in the structure of NN'DU molecule. Probably, NN'DU molecules are embedded in the crystal between the growth layers, which results in distortion of the crystal lattice and affects its strength properties.

It is known that the laser strength of crystals is mainly correlated with their me- chanical strength [30]. Taking into account the anisotropy of the mechanical properties of KDP crystal, the microhardness values were evaluated on two faces (001) and (100), and calculated from the formula (1). The results obtained with the optimum load on the indenter $(P=0.75 \mathrm{~N})$ are presented in Table 3 . Fig. 5 presents the loading curves of the growth sectors $\{101\}$ (a) and $\{100\}$ (b) on the face (001). The microhardness values obtained for the planes (001) and (100) of pure KDP crystal are similar to those already known [16]. The difference in the hardness of the faces (001) and (100) is due to their different crystallographic structure and to the fact that during their indentation different slip planes are activated [30].

The performed measurements showed that the doping of KDP:NN'DU crystal led to the rise of its hardening in the growth sec- 
tor $\{101\}$ by $15-20 \%$ (with a measurement error of $2 \%$ ), and to softening in the sector $\{100\}$ (Fig. 5, Table 3). The effect of NN'DU on the mechanical strength of the crystal may be due to changes in its structure and the interaction forces between the atoms [31], as well as to a decrease in the mobility of the point defects and the dopant molecules [32]. Different influence of NN'DU on the microhardness of $\{101\}$ and $\{100\}$ sectors of the KDP:NN'DU crystals is associated with different entering of the organic additive molecules into the growing faces, and with different nature of the interaction of the dislocations with NN'DU molecules in the $\{101\}$ and $\{100\}$ growth sectors.

The increase in the electrostatic attraction of $\mathrm{K}-\mathrm{O}$ as a result of a decrease in the parameters $c$ and $a$ of the crystal cell of KDP:NN'DU may give rise to a smaller decrease of LIDT in the sector $\{101\}$ (and also to an increase in mechanical strength) in comparison with LIDT (and mechanical strength) in the sector $\{001\}$ of the doped crystal relative to pure KDP (Table 3 ).

The results of measuring the radiation conversion efficiency into the second harmonic of KDP and KDP:NN'DU crystals are presented in Table 4. It has been found that at NN'DU concentrations of 0.15 and 0.45 wt. $\%$ the efficiency of SHG conversion of the doped crystals in the growth sector $\{100\}$ increases approximately by two times as against the one of pure KDP. The values of SHG conversion efficiency are practically the same for the $\{101\}$ growth sector of KDP:NN'DD crystals and pure KDP. These data correlate with the results obtained in [5]. In particular, when L-arg amino acid molecules were introduced into KDP crystal, there was observed the increase in SHG efficiency in the $\{100\}$ sector by 3.9 times compared to the one of the pure crystals; for the $\{101\}$ sector this efficiency increased by 2.5 times [5].

The increase of SHG efficiency in the $\{100\}$ sector relative to that for the $\{101\}$ sector in KDP:NN'DU crystal is probable due to both the entry of the molecules and the formation of additional hydrogen bonds between the molecules and the growing face of the crystal. It is known that the increase in the number of hydrogen bonds formed at the introduction of organic molecules into KDP crystals affect the efficiency of the SHG of the doped crystal $[12,13]$. In addition, local distortion of the crystal matrix and emergence of the corresponding polarization [7] may result from the appearance of an organic molecule in the growing crystal, which increases SHG efficiency.

\section{Conclusions}

It was found that KDP crystals grown from a mother liquor containing NN'DU molecules (with concentration of 0.15 and 0.45 wt. \%) had a transmission of 87-90\% in the visible spectral range and structural perfection. The presence of NN'DU molecules into both growth sectors $(\{100\}$ and \{101\}) of KDP crystals was confirmed by optical spectroscopy method, X-ray, differential thermal and thermogravimetric analyses. It was shown that the efficiency of SHG conversion in KDP:NN'DU crystals for the sector $\{100\}$ was higher by more than 2-time compared to the corresponding values of pure KDP. The introduction of NN'DU molecules into KDP crystal led to a decrease of LIDT in both growth sectors of the crystals; the microhardness in the sector $\{101\}$ increased by $17-32 \%$, but diminished in the sector $\{100\}$.

\section{References}

1. I.Pritula, V.Gayvoronsky, Yu.Gromov et al., Opt.Commun., 282, 1141 (2009).

2. K.D.Parikh, D.J.Dave, B.B.Parekh et al., Mater. Sci., 30, 105 (2007).

3. P.Kumaresan, S.Moorthy Babu, P.M.Anbarasan, Opt.Mater., 30, 1361 (2007).

4. D.J.Dave, K.D.Parikh, B.B.Parekh et al., $J$. Optoelectron.Adv. Mater., 11, 602 (2009).

5. R.C.Eckard, H.Masuda, Y.X.Fan et al., J. Quant. Electron., 26, 922 (1990).

6. I.M.Pritula, E.I.Kostenyukova, O.N.Bezkrovnaya et al., Opt. Mater., 57, 217 (2016).

7. E.I.Kostenyukova, O.N.Bezkrovnaya, M.I.Kolybaeva et al., Functional Materials, 23, 27 (2016).

8. V.Ya.Gayvoronsky, M.A.Kopylovsky, M.S.Brodyn et al., Laser Phys. Lett., 10, 035401 (2013).

9. I.M.Pritula, A.V.Kosinova, D.A.Vorontsov et al., J. Cryst. Growth, 355, 26 (2012).

10. I.V.Shnaidshtein, B.A.Strukov, S.V.Grabovskii et al., Phys. Solid State, 43, 2276 (2001).

11. D.Xue, S.Zhang, Physica B, 262, 78 (1999).

12. D.Xue, S.Zhang, J.Phys.Chem.Solids, 57, 1321 (1996).

13. D.Xue, S.Zhang, Chem.Phys. Lett.s, 301, 449 (1999).

14. R.Ledzion, P.Gorski, W.Kucharczyk, J.Phys. Chem. Solids, 68, 1965 (2007).

15. J.Podder, J. Cryst. Growth, 70, 237 (2002).

16. I.Pritula, A.Kosinova, M.Kolybayeva et al., Mater. Res. Bull., 43, 2778 (2008).

17. P.M.Wankhade, G.G.Muley, Res.Phys., 3, 97 (2013). 
18. G.G.Muley, M.N.Rode, B.H.Pawar, Optoelectron Adv.Mater-Rapid Commun., 3, 704 (2009).

19. W.L.Bond, Acta Crystallograph., 13, 814 (1960).

20. A.H.Compton, S.K.Allison, X-Rays in Theory and Experiment, D. Van Nostrand (1967).

21. J.E.Ayers, T.Kujofsa, P.Rago et al., Heteroepitaxy of Semiconductors: Theory, Growth, and Characterization. Taylor \& Francis Group (2017).

22. J.Ayers, J.Ladell, Phys.Rev.A ，37， 2404 (1988).

23. I.M.Pritula, A.V.Kosinova, O.N.Bezkrovnaya et al., Opt. Mater., 35, 2429 (2013).

24. N.Y.Garces, K.T.Stevens, L.E.Halliburton et al., J.Cryst. Growth, 225, 435 (2001).
25. P.Kumaresan, S.M.Babu, P.M.Anbarasan, J. Optoelectron. Adv. Mater., 9, 2780 (2007).

26. G.G.Muley, M.N.Rode, B.H.Pawar, Acta Physi Polonica A, 116, 1033 (2009).

27. S.A.de Vries, P.Goedtkindt, S.L.Bennett et al., Phys. Rev. Lett., 80, 2229 (1998).

28. X.Ren, D.Xu, D.Xue, J.Cryst.Growth, 310, 205 (2008).

29. D.Xu, D.Xue, J.Cryst.Growth, 286, 108 (2006).

30. C.H.Guin, M.D.Katrich, A.I.Savinkov et al., Kristall and Technik, 15, 479 (1980).

31. J.Podder, J. Cryst. Growth, 237, 1 (2002).

32. J.P.Hirth, J.Lothe, Theory of Dislocations, Wiley, New York (1982). 